\title{
8. STIMULATING EMPOWERMENT AND SUPPORTING ACCESS TO LEARNING FOR FORMALLY LOW-QUALIFIED ADULTS
}

\author{
Potentials of Work-Related Competency Assessment \\ in Social Enterprises
}

\section{INTRODUCTION $^{1}$}

Learning through work bears significant potential for formally low-qualified workers (Bolder \& Hendrich, 2000). This contribution describes the development of a work-related competency assessment procedure to be used in Social Enterprises. The validation and recognition of learning outcomes is crucial for educationally disadvantaged adults with a biography in the world of work. Being identified as formally low-qualified does not necessarily mean being low-skilled. Fostering and facilitating work-related learning is key to job-related development (labour skills) and self-development (personal stabilisation and life skills) for this group at risk. Taking a close look at knowledge, skills and competences can stimulate empowerment and support access to learning. Referring to Honneth's Theory of Recognition (2003), the competency assessment procedure aims at improving disadvantageous learning preconditions in terms of developing a positive learning identity. Furthermore, it aims at providing formally low-qualified adults with a basic vocational qualification, which is aligned with the development of a National Qualifications Framework in Austria, referring to the potential of Qualifications Frameworks as a contribution to an equal and permeable society (Blings \& Ruth, 2012; Büchter, Dehnbostel, \& Hanf, 2012).

\section{WORKING AND LEARNING IN SOCIAL ENTERPRISES}

This chapter focuses on an educational intervention for educationally disadvantaged adults. It presents the results of the R\&D project Competency Amelioration through Competency Assessment (German project acronym: KOMKOM), funded by the Austrian Federal Ministry of Education (September 2011 to March 2015). ${ }^{2}$ The KOMKOM project focused on formally low-qualified employees working in government-funded Social Enterprises. Social Enterprises are part of the Austrian active employment policy. They aim at the (re-)integration of the longterm unemployed into the labour market via temporary employment (instructed 
work and work-related learning), counselling and guidance, and the provision of additional seminars (for instance on literacy or on German as a second language). Work instructors and personnel developers provide guidance and support, which facilitates work-related and therefore practical learning. They can be found in different business sectors, such as the food service, retail, agriculture/gardening, or technical/craft-based services. There are about 200 Social Enterprises in Austria (Arbeit Plus, 2016).

Temporary employment in Social Enterprises offers various possibilities for gaining evidence from work for competency assessment. The KOMKOM competency assessment procedure was developed in collaboration with Social Enterprises and their umbrella organisation Arbeit Plus. We pursued two objectives within the KOMKOM project. One was to develop a flexible tool for competency assessment of employees (the so-called transit workers) in Social Enterprises. Second, we aligned this tool with level 1 and level 2 (these are the lowest levels) of the Austrian National Qualifications Framework (NQF). This project approach aims at social inclusion and participation through adult education.

The KOMKOM project builds on two projects funded by the European Union (EU). SYSCOM - Systematic Competency Documentation in Social Integration Enterprises (2009 to 2010) produced two results: Various tools already exist to document learning outcomes and validate prior learning. Social Enterprises should participate in the implementation of National Qualifications Frameworks in order to support their target groups (European Network of Social Integration Enterprises [ENSIE], 2015). Within the context of the second project, NQF inclusive Accreditation and certification of basic vocational education for disadvantaged people (2009 to 2011), vocational qualifications have been developed on NQF levels 1 and 2 for people with disabilities (NQF inclusive, 2011). ${ }^{3}$

The KOMKOM competency assessment procedure provides an example of a basic qualification for technical/craft-based services (prototype) on a fundamental and, therefore, easily achievable level. The tool consists of several learning areas with learning outcomes and identification traits. It is designed for self-assessment and for the assessment by others. A validation conversation follows the assessments. In this setting, the employee and work instructor/personnel developer compare and discuss the results and jointly consider the next steps for learning/development. This procedure helps to identify existing knowledge, skills and competences. It provides evidence and a basis for individual development via work-related learning. The KOMKOM qualification has a pronounced vocational education approach suitable for adults with a biography in the world of work. Furthermore, the learning outcomes cover the whole spectrum, and go (far) beyond labour market skills. The procedure is intended to empower the (often falsely and misleadingly so-called) 'low-skilled' workers. Taking a very close look at their knowledge, skills and competences makes them visible. As a secondary consequence, this approach supports the development of a positive learning career, by revealing the capabilities they already possess and those they have recently acquired. The KOMKOM competency assessment is 
aligned with the Austrian National Qualifications Framework, which is based on the European Qualifications Framework (EQF). Defined KOMKOM learning outcomes correspond with NQF descriptors on level 1 and 2, allowing an official qualification (certificate) to be awarded prospectively. Opportunities of gaining horizontal labour mobility can be expected and access to (formal) qualifications would be a possibility in the future. The focus of the R\&D follow-up project (planning stage) will be on studying various impacts of this educational intervention.

\section{LITERATURE REVIEW}

\section{Theoretical Background}

Honneth's Theory of Recognition (2003) provides the theoretical foundations for the KOMKOM approach, both from an individual and a societal perspective. Honneth (Frankfurt school) defined three patterns of intersubjective recognition: Love, Justice and Solidarity. Educational disadvantage is closely related to power, recognition, and respect. The validation and recognition of prior learning is a matter of respect, fairness and solidarity towards groups at risk. Competency assessment is about making individual capabilities visible. The recognition of non-formal and informal learning outcomes is crucial for formally low-qualified adults. In this regard, we refer to Honneth's concept of Love by taking a close look at the knowledge, skills and competences of formally low-qualified adults on an individual basis and in an encouraging and appreciative way. We argue that this approach modifies disadvantageous learning preconditions in terms of developing a positive learning identity. This can be seen as a precondition for participating in lifelong learning activities. Opening non-traditional ways of gaining valuable certificates via NQF is a matter of power, because it empowers groups at risk. Furthermore, the NQF is a revolutionary undertaking for Austria, since the formal educational sector is very strong and key players are very powerful. Opening non-traditional ways for learners via the learning outcomes approach is more akin to a revolution (and not a reform) for the Austrian educational system. In this regard, we refer to Honneth's concept of Justice. Finally, we understand Honneth's concept of Solidarity as represented in the Social Enterprises themselves, because they aim at a just and sustainable society. They represent networks of solidarity with shared values. The KOMKOM approach aims at supporting the Social Enterprises' specific learning environments provided for educationally disadvantaged transit workers.

Dehnbostel (2011) described Qualifications Frameworks and validation processes as located between 'Bildung' (education) and economy. He analysed the sharp distinction between pedagogical approaches to support self-development on the one hand and assessment procedures to match occupational requirements and employees on the other. Referring to Dehnbostel, KOMKOM aimed at developing a validation procedure, which equally supports self-development and empowerment as well as employability, by providing a basic vocational qualification. Within KOMKOM we 
referred to the scientific debate on social inclusion, participation and adult education (Kronauer, 2010; Burtscher et al., 2013). We understood NQF level 1 and NQF level 2 as an entry opportunity for the educationally disadvantaged. KOMKOM aimed at providing a basic qualification (official certificate) on a fundamental and therefore easily achievable level for formally low-qualified workers who do not hold a formal vocational qualification. KOMKOM aimed at providing this group at risk (formally low-qualified unemployed/long-term unemployed) with a basic vocational qualification. Referring to Reutter (2010), we understood this as a contribution to social inclusion provided by adult/continuing education. The validation of learning outcomes is the main key to making individual capabilities visible. Within KOMKOM we argued that our approach could support the development of a positive learning career. The procedure is intended to empower the transit workers. Opportunities of gaining horizontal labour mobility, which means finding a (better) job, can be expected. Access to (formal) qualifications on upper NQF levels, based on the basic KOMKOM qualification, would be a possibility in the future.

\section{Empirical Background}

In its recommendation on the validation of non-formal and informal learning the Council of the European Union (2012) stated that 'disadvantaged groups, including individuals who are unemployed and those at risk of unemployment, are particularly likely to benefit from the validation arrangements, since validation can increase their participation in lifelong learning and their access to the labour market'. This assumption also emerged from the SYSCOM project, which served, as previously mentioned, as an important foundation for the KOMKOM project. If KOMKOM competency assessment procedures were widely in use, this assumption could be examined and would hopefully prove true for the formally low-qualified workers in Social Enterprises. Here, we refer (red) to the scientific debate on the potential of Qualifications Frameworks as a contribution to a just/equal and permeable society (Blings \& Ruth, 2012; Büchter, Dehnbostel, \& Hanf, 2012; cf. recently Gutschow, 2014).

The KOMKOM approach aims at formally low-qualified, severely disadvantaged adults, working in Social Enterprises. So, what does educational disadvantage mean in Austria? For KOMKOM we focused on formally low-qualified adults who had - at best - completed compulsory school (9 years). This is the lowest formal qualification and it is a general education, not a vocational education. According to labour market data, people with a low formal qualification are at risk of becoming and remaining unemployed (there is a risk of 24 per cent for this group compared to a risk of 7 per cent for those with an apprenticeship qualification). People without a formal qualification beyond compulsory schooling make up almost half of those registered as unemployed (47 per cent) with the Public Employment Service (Arbeitsmarktservice [AMS], 2015).

Bolder and Hendrich (2000) presented a highly relevant finding in their book Fremde Bildungswelten, which can be translated as 'strange educational worlds': 
formally low-qualified adults tend to maintain a certain distance to formalised continuing education settings such as seminars and training courses. The authors identified a certain connectivity of this target group to workplace learning and therefore to practical learning. This empirical finding further strengthens the bond between working and learning, which enables individual competency amelioration through work (cf. also Dehnbostel, 2007, 2010). In Social Enterprises, practical learning and work-based learning are fostered through practical instructions and concrete guidance, supported by Human Resources Development (HRD) measures. The KOMKOM procedure offers an evidence-based foundation for those measures, which are already in use in Social Enterprises. Validation and recognition of prior learning is part of the European educational policy. CEDEFOP's (European Centre for the Development of Vocational Training) guidelines for validating non-formal and informal learning define several routes from learning outcomes to certification. When it comes to assessment methods, "simulation and evidence extracted from work" (CEDEFOP, 2009, p. 62) are described. The Social Enterprises offer various possibilities for gaining evidence from work, e.g. observations, interviews, feedback. These methods of gaining evidence are incorporated in the KOMKOM procedure as well.

A recent evaluation study (over a period from 2005 to 2012) on Social Enterprises concerning the formal educational background showed that 56 per cent of the transit workers hold the lowest formal qualification, which is compulsory (and thereby general education) on the lower secondary level (Eppel et al., 2014, p. v). Included in this group are approximately 8 per cent who have not completed any kind of formal qualification at all. So, more than half of all transit workers do not hold a formal vocational education/training qualification (vocational track involves apprenticeship qualification or vocational school qualification [VET]). The evaluation study showed that transit workers with a higher formal qualification are more successful at re-integrating into the labour market (effectiveness). The authors argued for developing suitable learning facilities for the formally lowqualified transit workers and strengthening the bond between working and learning in Social Enterprises (ibid., p. xxxix). There is strong evidence for the adequacy of the KOMKOM approach.

\section{European and National Policies on Education}

The Austrian policies on education refer to the EU's policies. The member states have been instructed to develop national strategies for lifelong learning. The Austrian strategy for lifelong learning (Republik Österreich, 2011) includes 10 goals. One task is concerned with promoting and facilitating workplace learning. Another task aims at valuing informal and non-formal learning outcomes. This task is linked to the development of the National Qualifications Framework in Austria. The EQF is a translation tool that facilitates communication and comparison between the qualification systems of the 28 member states. The eight European reference levels are described in terms of learning outcomes: knowledge, skills and competences. 
This allows any national qualifications systems, national qualifications frameworks and qualifications in Europe to relate to the EQF levels. Learners, graduates, providers and employers can use these levels to understand and compare qualifications awarded in different countries and by different education and training systems (European Commission, 2015a).

Austria does not have a tradition of recognising non-formal and informal learning outcomes. Consequently, the EQF was a stimulus to develop a NQF in Austria, which meant quite a shift in the national educational system, especially for the institutions of formal learning (in terms of their self-conception). As part of the development of the Austrian NQF, the national EQF referencing report (Federal Ministry of Education, Arts and Culture [BMUKK] \& Federal Ministry of Science and Research [BMWF], 2011) was published. Procedures for referencing qualifications to the NQF needed to be developed. It was divided into three 'corridors': formal qualifications in corridor $1(\mathrm{~K} 1)$, non-formal learning outcomes in corridor 2 (K2) and informal learning outcomes in corridor 3 (K3). As a first step, criteria for referencing formal qualifications (K1) to the NQF have been developed (Nationale Koordinierungsstelle für den NQR in Österreich [NKS], 2011). The KOMKOM qualification was selected to be referenced to the NQF as a qualification in the non-formal learning corridor (Tritscher-Archan et al., 2013). The KOMKOM qualification successfully passed through this national simulation procedure. The Austrian Federal Ministry of Education initiated a national consultation process on the validation of non-formal and informal learning, concerning goals, measures, organisational structures and standards for the validation of learning outcomes (Bundesministerium für Bildung und Frauen [BMBF], 2015). By the end of 2015, a legislative proposal on a federal law on the NQF has been published (Republik Österreich, 2015). The adoption of the NQF-Act by the National Council and Federal Council gave the NQF in Austria a legal foundation in March 2016. The act regulates the mapping process and enables further implementation of the NQF in Austria (Republik Österreich, 2016; NKS, 2016).

\section{METHODS: DEVELOPING THE KOMKOM APPROACH}

\section{Guiding Principles}

When it comes to educationally disadvantaged adults, or more precisely, formally low-qualified workers, the list of significant questions includes the following: Are these adults capable of MORE than their certificates (if they hold any at all) prove? What EXACTLY are they capable of? As noted above, more than half of all transit workers have only completed compulsory education at most, and have not gained a formal vocational qualification. Nevertheless, being seen or identified as formally low-qualified does not necessarily mean being low-skilled. Therefore, it is crucial to document any kind of knowledge, skills and competences. Temporary employment 
in Social Enterprises offers the possibility of competency assessment. The validation of learning outcomes is the main key to making individual capabilities visible. Qualifications Frameworks as described above provide the basis for this approach. The most important principle of the EQF is the learning outcomes approach. The learning outcomes approach shifts focus to what knowledge, skills and competences the learner has acquired by the end of the learning process (European Commission, 2015b). The references for the KOMKOM qualification are NQF levels 1 and 2. In the Austrian EQF Referencing Report those two levels are defined as in Figures 1 and 2 (BMUKK \& BMWF, 2011).

A main principle guiding the definition of KOMKOM learning outcomes was the objective of inclusion. EVERY person working in a Social Enterprise would be able to reach level 1, so none would be in danger of being excluded. Level 1 was understood as an entry opportunity for the educationally disadvantaged, and this door needs to be wide open. The key to inclusion was encapsulated in the following statement, which expresses the expected amount of support and autonomy granted on level 1: "In his/her field of work or study he/she is able to deal with simple situations under given framework conditions and with corresponding assistance" (cf. Figure 1). With a sufficient amount of support and time, every single identification trait within the KOMKOM competency assessment is achievable by everyone. So ultimately, level 1 would really work as an entry into the Austrian NQF.

Within KOMKOM we aimed at providing an evidence-based foundation for daily work (e.g. work instructions and HRD) in Social Enterprises. Nota bene the KOMKOM qualification procedure works on a voluntary basis, it is meant to be an offer within the Social Enterprises. This corresponds fully with CEDEFOP's guidelines "that the process of making visible the full range of knowledge, skills and competences held by an individual is carried out in a way that remains voluntary and that the results of validation remain the property of the individual" (CEDEFOP, 2009, p. 50). When a new employee has her/his first interview in the Social Enterprise, she/ he is provided with information about the possibility to participate in the KOMKOM assessment procedure. As such, the suggestion to participate is embedded within guidance and HRD measures.

During the national simulation procedure for the non-formal learning corridor (K2), the KOMKOM team consistently argued that the required knowledge- and skills-level on level 1 has been set too high in the Austrian EQF Referencing Report (see Figure 1), and individuals therefore could be excluded. Here, KOMKOM acted as an advocate for the formally low-qualified. Rethinking the descriptors on level 1 has been a learning drawn from the national simulation procedure, based on the KOMKOM input. However, the realisation of a possible redefinition of descriptors remains pending and is actually unlikely to come to fruition.

One crucial aspect is the required fundamental knowledge of reading, writing, arithmetic and use of modern information and communication technologies, especially on level 1 (that should work as an easily achievable entry into the NQF). 


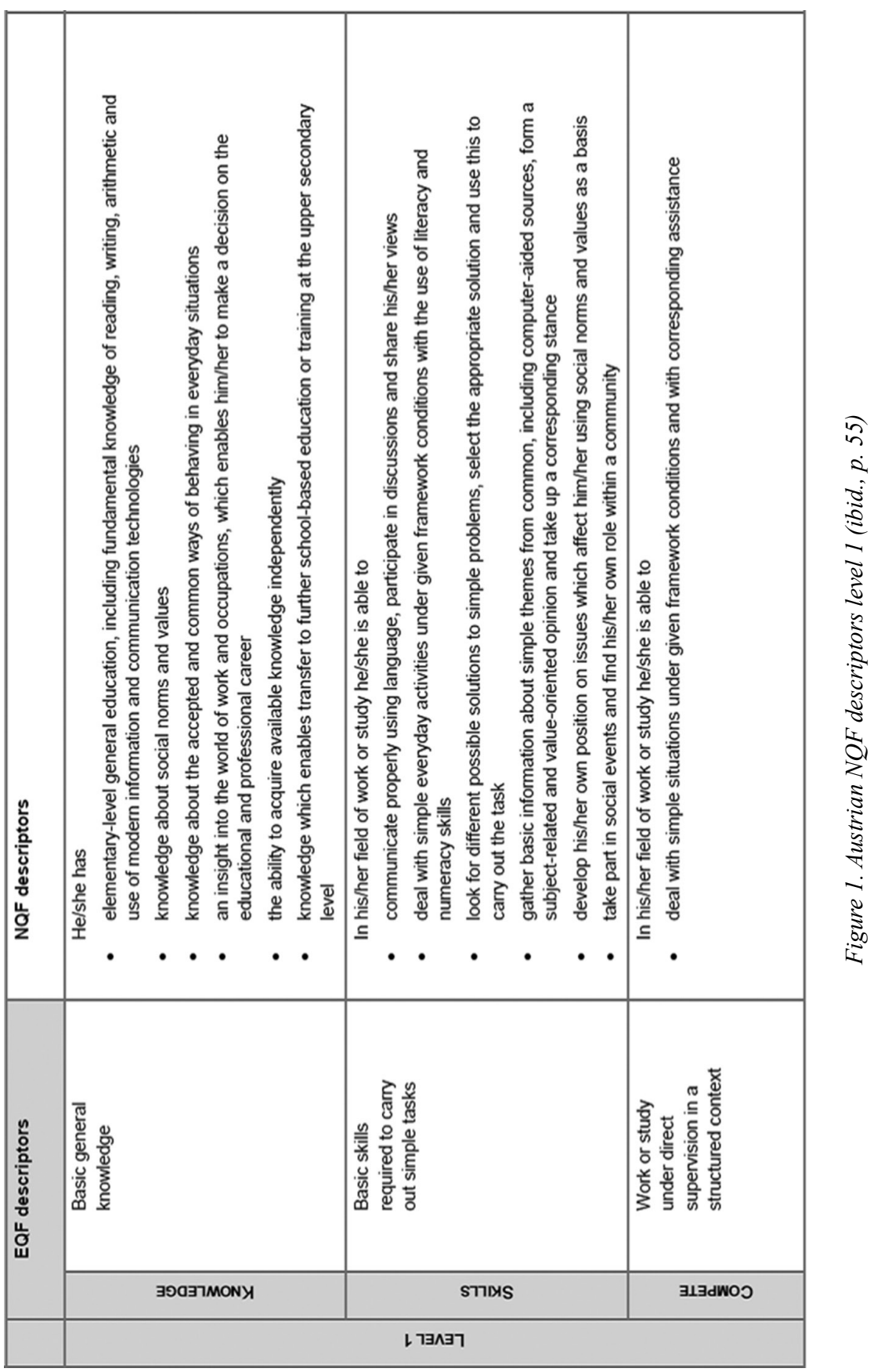




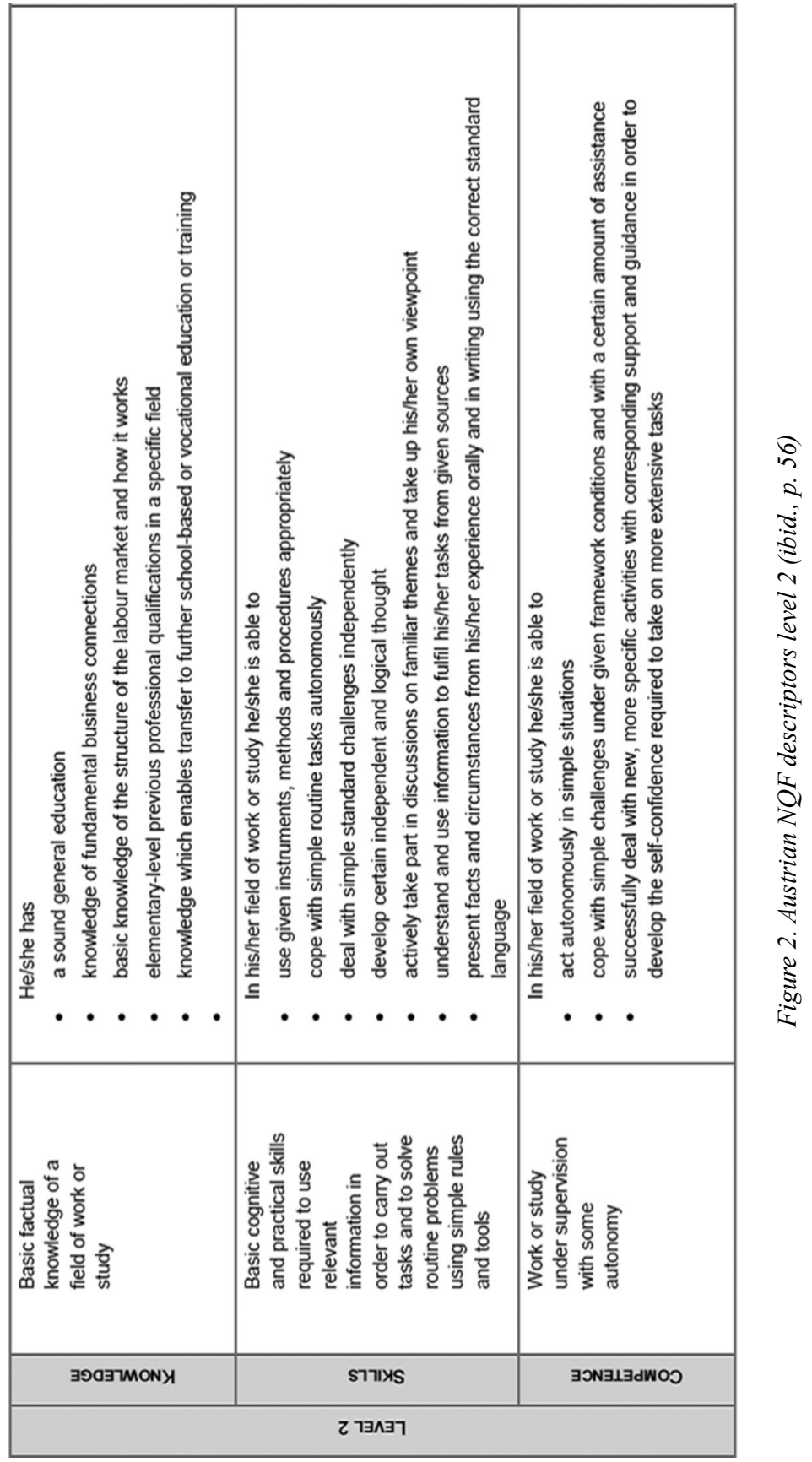


Possessing this 'fundamental' amount of knowledge cannot be seen as given, as the PIAAC results (Programme for the International Assessment of Adult Competencies) for Austria revealed (Organisation for Economic Co-operation and Development [OECD], 2013). Showing a low proficiency in literacy, numeracy, and problem solving in technology-rich environments is closely related with holding the formal lowest qualification (compulsory education at most), but low proficiency is also found within the group that has gained an apprenticeship certification (Kastner \& Schlögl, 2014). Within the KOMKOM assessment procedure, basic skills (reading, writing, numeracy, and ICT skills) have been included as work-related skills and life skills, which deserve and need to be developed.

As mentioned above, practical, work-related learning is seen as suitable for educationally disadvantaged adults. Their learning experiences are closely connected with school, and (quite often) with painful or unpleasant memories. Such conditions do not support a positive attitude towards further learning. Within the KOMKOM assessment procedure, 'learning to learn' is therefore included as a learning outcome. The aim is to help to develop a positive learning career, and gain self-esteem with respect to learning. The KOMKOM procedure aims at building capacities.

\section{Research-Based Development}

The KOMKOM competency assessment procedure was developed in collaboration with several Social Enterprises and their umbrella organisation Arbeit Plus. Different research methods and development methods were applied:

- Literature study on the state of the art regarding competency discourses and on assessment procedures for the disadvantaged, mainly for people with disabilities

- Questionnaires sent out to Social Enterprises: which tools are already in use and what are the requirements concerning a new tool for competency assessment

- Working groups with invited experts: discussions of facts and approaches (for instance with P. Dehnbostel)

- Observations in several Social Enterprises: workplaces, requirements, instructions

- Definition of learning outcomes and identification traits according to the NQF descriptors ('translating' these requirements) and based on the preliminary work (various prototypes/redefinition)

- Testing of prototypes with learners and work instructors/personnel developers in several Social Enterprises

- Focus groups with relevant stakeholders

- Presentations of steps and findings in relevant groups (learners, work instructors/ personnel developers)

- Presentation of steps and findings at conferences and in publications, using both channels for science-to-science communication and those for science-toprofessionals communication 


\section{RESULTS: THE KOMKOM PROCEDURE}

\section{The KOMKOM Assessment: Tool and Process}

The KOMKOM procedure can be used at least twice during a period of temporary employment (six to twelve months). First, at the beginning of the employment, in order to assess the starting point in terms of documentation of existing capabilities. A second time at the end, in order to assess the competency amelioration, while an optional third assessment can be scheduled sometime around the middle of the employment period (in terms of assessing recently developed knowledge, skills and competences, and of documenting progress). The assessment procedure consists of self-assessment and assessment by the work instructors/personnel developers, followed by a validation conversation. The aim is to provide evidence for further work-related development and self-development. Individual development achieved during the employment becomes visible and provides a valid basis for further steps, e.g. concrete work instructions, HRD measures, and suitable seminars (if required).

The prototype assessment tool for the technical/craft-based services consists of 70 learning outcomes based on approximately 200 identification traits. The learning outcomes are defined for 14 areas, which are assigned to the three main competences:

Professional and method competence: vocational knowledge and skills; profession-related arithmetic; basic and work-related ICT competence; work-related literacy (oral expression, writing); knowledge and skills for dealing with working life \& labour market requirements;

Social and communicative competence: knowledge and skills for teamwork, communication, and participation; ability to handle and express criticism; diversity competence;

Personal competence: ability to accept responsibility; organizational competence; ability to deal with work-related problems and every-day-life challenges; learning to learn.

Assessment involves the rating of identification traits. The wording in the four different answer categories depends on the wording in the identification traits (knowing, doing something). In general, the categorisation works as follows:

Table 1. Rating categories

\begin{tabular}{llll}
\hline Major learning need & $N Q F$ level 1 & NQF level 2 & Beyond NQF level 2 \\
\hline $\begin{array}{l}\text { I still have to learn } \\
\text { this. }\end{array}$ & With a lot of support, & With a little support, & No support necessary, \\
& I am able to ... & I am able to ... & I am perfectly able to ... \\
\hline
\end{tabular}

The employees use the tool for self-assessment. It runs on a tablet computer. The tool uses Easy-to-Read language. There is a voice output in German for those who like to listen and prefer not to read, which also works as a support for improving 
reading skills in German. The categorisation of the identification traits works by answering by selecting buttons with icons (rating). The four rating categories make learning needs visible. The tool provides a colour guidance system, and it shows information about the progress.

The work instructors/personnel developers perform the assessments of the employees on a PC. Each learning outcome is furnished with its identification traits as a reminder of what exactly is covered by each learning outcome during the rating.

A validation conversation follows the self-assessment and the assessment by others. The tool produces a comparison document, where the employee's rating and employer's rating are printed side by side. This is the pedagogical moment, where self-assessment results and the work instructor's/personnel developer's view are put together and discussed in an encouraging way. This is the place to compare the two views regarding the employee's knowledge, skills and competences. Understanding differing results can be seen as a contribution to developing a realistic and positive self-concept, because over-estimation (and more likely) under-estimation can be indicative of a weak self-concept. The focus during the validation conversation is on the individual's strengths and achievements, and on potential for (further) improvement and development. The identification traits help to specify work instructions and HRD measures: where exactly is the learning need, what exactly needs to be trained to achieve this learning outcome in terms of agreeing upon future steps to take. We suppose that all in all the documentation of existing capabilities and recently developed learning outcomes is a positive learning experience.

\section{The KOMKOM Qualification: NQF Certificate and Its Supplement}

As it stands at the moment, the KOMKOM assessment tool provides a basic qualification for technical/craft-based services (prototype). The assessed learning outcomes are the foundations for awarding a NQF certificate, in the best scenario for NQF level 2. The aim is that, within a period of temporary employment, an employee would be able to develop her/his knowledge, skills and competences up to NQF level 2 (or even better in some learning areas). The decision about whether to gain a NQF certificate or not is accompanied and guided by the work instructors and personnel developers. It should not be awarded automatically.

If an employee wants to acquire a NQF certificate, the ultimate assessment by others is carried out by two work instructors/personnel developers (double verification principle). Again, a concluding validation conversation follows selfassessment and assessment by others. Finally, a NQF certificate with detailed information and the personalised supplement can be printed. The NQF certificate and its supplement name the qualification (for the prototype: basic qualification for technical/craft-based services), and a summary of the learning outcomes within the 14 learning areas is listed and described, and references to the particular NQF level are specified. Learning areas with high scores (beyond NQF level 2) are placed at the top of the supplement, followed by the learning areas where level 2 was achieved, (if 
relevant) followed by the learning areas where level 1 was achieved. The certificate also provides information about the Austrian NQF (level 1 to level 4).

Prospectively, a NQF certificate would be an official qualification for technical/ craft-based services (and others to follow), which is referenced to the NQF. This certificate documents learning outcomes, and could therefore work as a link to continuing education and the formal VET system, given that lifelong guidance for the educationally disadvantaged is thus (further) improved in Austria. In the meantime, the document works as a valid and conclusive certificate of employment and serves as a detailed job reference.

\section{CONCLUSION \& FUTURE PROSPECTS}

Findings so far and future prospects are closely connected. A follow-up R\&D project is in preparation. In the meantime, a Social Enterprise included the KOMKOM procedure within a new project for formally low-qualified adults (offering training for building and repair service). In 2017, this cooperation will provide the opportunity to evaluate the KOMKOM procedure and it will enable to answer some of the following questions. ${ }^{4}$

\section{Future Project Steps}

The follow-up project includes different work packages.

- A training course for work instructors and personnel developers in Social Enterprises is to be developed. The KOMKOM tool is expandable and adjustable, which means that learning outcomes and identification traits can be adapted (to a certain extent) to the particular Social Enterprise. The definition of learning outcomes that refer to the NQF correctly requires training. Furthermore, the training course aims at improving adult educational professionalisation. Participants learn to conduct the validation conversation, e.g. name and discuss strengths and learning needs, and to agree upon future work-related steps to take. Of course, all of this is based on prevailing guidance principles for the educationally disadvantaged (Gieseke, 2014).

- Learning outcomes for agriculture/gardening, based on the KOMKOM prototype, have been defined already, and further learning outcomes for other occupational fields are to be defined (service sector: food service, retail). The KOMKOM approach could be suitable for other occupational fields, where work-related learning takes place, e.g. sheltered employment for people with disabilities or employment/learning facilities in prisons.

- The KOMKOM qualification for technical/craft-based services needs to be developed for NQF level 3. This is the missing link to an apprenticeship qualification (NQF level 4; cf. BMUKK \& BMWF, 2011, p. 58). An apprenticeship qualification is a significant formal vocational qualification, and there are currently almost 200 different apprenticeships in Austria. Level 3 needs more profound 
vocational differentiation within the learning outcomes. It has to be defined with a more strategic direction towards one or more apprenticeships to secure a certain amount of connectivity towards an extraordinary apprenticeship examination.

- Furthermore, there are plans to provide the users not only with the voice output in German to support reading skills in German. Voice output in other languages, which are widely in use in Austria because of immigration would also be necessary.

- A main work package of this follow-up is to test and improve the KOMKOM assessment procedure (evaluation). We need to know how useful the KOMKOM procedure is for the work instructors and personnel developers in their daily work in Social Enterprises. How good is the usability? Is it a valid procedure? Does it provide personnel with a valid basis for identifying appropriate measures?

\section{Studying the Impacts of KOMKOM}

We need to study the various impacts of the KOMKOM procedure as an educational intervention. The framework for this accompanying research will be the findings presented as the theoretical and empirical backgrounds of the KOMKOM R\&D project (see above). Main research questions will be the following:

- We assume that the assessment procedure provides the employees with positive learning experiences and enables the development of a positive learning career (empowering the ability to learn, building capacities). The procedure could therefore help to select and engage in continuing education.

- We assume that the assessment procedure helps individuals to cope (better and more successfully) with job interviews, because (future) employees are able to name individual and work-related knowledge, skills and competences, based on identification traits and learning outcomes they became used to talking about in the validation conversations. Reporting about past learning progress and strengths in a structured way could be helpful in job-application situations.

- We assume that educationally disadvantaged groups will welcome an official NQFrelated certificate. Schools on the lower secondary level place emphasis on general education. Meanwhile, the KOMKOM qualification has a pronounced vocational education approach, which is more suitable for adults with many years of experience of life, including work. Furthermore, within the KOMKOM target group, there are adults who have attended a special needs school or who have left compulsory education with a negative final report. Presenting such reports in job interviews is degrading and insulting. Furthermore, within the KOMKOM target group there are adults who have completed a prevocational school (one year to fulfil compulsory education), but this certificate is not highly esteemed. A neutral and basic vocational qualification via the NQF could be helpful for those who lack valuable certificates.

- We need to know how (future) employers assess the KOMKOM qualification (NQF certificate and supplement). Do they appreciate the learning outcomes approach and regard the detailed certificate as helpful in job interviews? Does a 
KOMKOM certificate provide sufficient information about managing future job requirements successfully? Is the KOMKOM certificate seen as a positive signal within the labour market?

- Finally, regarding the KOMKOM approach, which means using the NQF for inclusion (Kastner, 2016), we need to study if the Austrian NQF has the potential to include the educationally disadvantaged via validation and recognition of learning outcomes acquired outside the formal educational system.

\section{NOTES}

1 A slightly different version of this topic was presented at the 9th International Conference on Researching Work \& Learning, 8-12 December 2015 in Singapore, entitled Promoting learning through work for formally low-qualified workers.

2 R\&D made possible thanks to the Federal Ministry of Education, Department of Adult Education. Special thanks go to Gabriela Khannoussi-Gangoly for her unwavering interest in the KOMKOM project.

3 The KOMKOM project was developed and carried out by the Austrian SYSCOM coordinator Hedwig Presch, psychologist and expert for labour market/work and learning; the NQF inclusive lead Marion Bock, educationalist, project developer and manager at 'Chance B', a provider of social services; Irmgard Kaufmann-Kreutler, expert for adult literacy, low-threshold adult education, and technical vocational training for women; Monika Kastner, educationalist and education researcher (KOMKOM lead). Many thanks go to my KOMKOM colleagues Marion, Irmgard and Hedwig, for it is always a pleasure to work with you and learn from you.

4 Information can be retrieved from www.komkom.at (currently only available in German).

\section{REFERENCES}

Note: Internet references most recently retrieved and verified on December 22, 2016.

AMS. (2015). Arbeitsmarkt \& Bildung. Jahr 2014. Retrieved from http://www.ams.at/_docs/001_am_ bildungJahr2014.pdf

Arbeit Plus. (2016). Association of social enterprises in Austria: A network of social entrepreneurs. Retrieved from http://arbeitplus.at/english/

Blings, J., \& Ruth, K. (Eds.). (2012). Transparenz und Durchlässigkeit durch den EQR? Perspektiven zur Implementierung. Bielefeld: Bertelsmann.

BMBF. (2015). Konsultationsdokument. Validierung nicht-formalen und informellen Lernens. Entwicklung einer nationalen Strategie zur Umsetzung der Ratsempfehlung vom 20.12.2012 (2012/C/398/01). Retrieved from http://www.bildung.erasmusplus.at/fileadmin/lll/dateien/lebenslanges_lernen_pdf_ word_xls/nqr/EQF_Advisory_Group_Meetings/Validierung_non-formalen_und_informellen_ Lernens/Konsultationspapier_Beilage_pdf

BMUKK \& BMWF. (2011). Austrian EQF referencing report. Retrieved from https://ec.europa.eu/ ploteus/documentation\#documentation_73

Bolder, A., \& Hendrich, W. (2000). Fremde Bildungswelten. Alternative Strategien lebenslangen Lernens. Opladen: Leske+Budrich.

Burtscher, R., Ditschek, E. J., Ackermann, K.-E., Kil, M., \& Kronauer, M. (Eds.). (2013). Zugänge zu Inklusion. Erwachsenenbildung, Behindertenpädagogik und Soziologie im Dialog. Bielefeld: Bertelsmann.

Büchter, K., Dehnbostel, P., \& Hanf, G. (Eds.). (2012). Der Deutsche Qualifikationsrahmen (DQR). Ein Konzept zur Erhöhung von Durchlässigkeit und Chancengleichheit im Bildungssystem? Bielefeld: Bertelsmann.

CEDEFOP. (2009). European guidelines for validating non-formal and informal learning. Luxembourg: Office for Official Publications of the European Communities. 


\section{KASTNER}

Council of the European Union. (2012). Council recommendation of 20 December 2012 on the validation of non-formal and informal learning (2012/C 398). Retrieved from http://eur-lex.europa.eu/legalcontent/EN/TXT/?uri=CELEX:32012H1222(01)

Dehnbostel, P. (2007). Lernen im Prozess der Arbeit. Münster: Waxmann.

Dehnbostel, P. (2010). Betriebliche Bildungsarbeit. Kompetenzbasierte Aus- und Weiterbildung im Betrieb. Baltmannsweiler: Schneider Verlag Hohengehren.

Dehnbostel, P. (2011). Qualifikationsrahmen: Lernergebnisorientierung und Outcomeorientierung zwischen Bildung und Ökonomie. Magazin erwachsenenbildung.at. Das Fachmedium für Forschung, Praxis und Diskurs, 14, 05-1-05-11 (E-Journal). Retrieved from http://erwachsenenbildung.at/ magazin/archiv_artikel.php? $\mathrm{mid}=5847$ \&aid $=5850$

ENSIE. (2015). SYSCOM: Systematic competency documentation in social integration enterprises. Retrieved from http://www.ensie.org/syscom

Eppel, R., Horvath, T., Lackner, M., Mahringer, H., Hausegger, T., Hager, I., Reidl, C., Reiter, A., Scheiflinger, S., \& Friedl-Schafferhans, M. (2014). Evaluierung von Sozialen Unternehmen im Kontext neuer Herausforderungen. Evaluierung im Auftrag des Bundesministeriums für Arbeit, Soziales und Konsumentenschutz durch WIFO - Österreichisches Institut für Wirtschaftsforschung und prospect Unternehmensberatung GesmbH. Retrieved from http:/www.wifo.ac.at/publikationen?detailview=yes\&publikation_id=50690

European Commission. (2015a). Learning opportunities and qualifications in Europa: Find information on the EQF, NQF's. Retrieved from https://ec.europa.eu/ploteus/search/site?f[0] =im_field_entity type $\% 3 \mathrm{~A} 97 \#$

European Commission. (2015b). How does the EQF work? Retrieved from https://ec.europa.eu/ploteus/ content/how-does-eqf-work

Gieseke, W. (2014). Konzept- und Strukturanforderungen für die Beratung von gering Qualifizierten. In Projektträger im DLR (Ed.), Kompetenzen von gering Qualifizierten. Befunde und Konzepte (pp. 89-100). Bielefeld: Bertelsmann.

Gutschow, K. (2014). Chancen der Kompetenzanerkennung für gering Qualifizierte. In Projektträger im DLR (Ed.), Kompetenzen von gering Qualifizierten. Befunde und Konzepte (pp. 33-46). Bielefeld: Bertelsmann.

Honneth, A. (2003). Kampf um Anerkennung. Zur moralischen Grammatik sozialer Konflikte. Frankfurt am Main: Suhrkamp.

Kastner, M. (2016). Inklusion durch Erwachsenenbildung - mehr als nur eine utopische Hoffnung? Eine Bildungsintervention für formal gering qualifizierte Erwachsene im Kontext des Nationalen Qualifikationsrahmens.bwp@Berufs- und Wirtschaftspädagogik Online, Ausgabe 30 (E-Journal). Retrieved from http://www.bwpat.de/ausgabe30/kastner bwpat30.pdf

Kastner, M., \& Schlögl, P. (2014). Fundamente gesellschaftlicher Teilhabe. Neues empirisches Wissen aus der PIAAC-Erhebung zu den unteren Kompetenzniveaus. In Statistik Austria (Ed.), Schlüsselkompetenzen von Erwachsenen. Vertiefende Analysen der PIAAC-Erhebung 2011/12 (pp. 256-278). Wien: Statistik Austria.

Kronauer, M. (Ed.). (2010). Inklusion und Weiterbildung. Reflexionen zur gesellschaftlichen Teilhabe in der Gegenwart. Bielefeld: Bertelsmann.

NKS. (2011). Handbuch für die Zuordnung von formalen Qualifikationen zum Nationalen Qualifikationsrahmen (NQR) - Kriterien. Wien: Nationale Koordinierungsstelle für den NQR in Österreich (NKS).

NKS. (2016). Development of the NQF in Austria. Retrieved from https://www.qualifikationsregister.at/ public/Entwicklung\#

NQF inclusive. (2011). Accreditation and certification of basic vocational education for disadvantaged people via NQF. Retrieved from http://www.nqfinclusive.org/index.php?1=1

OECD. (2013). OECD skills outlook 2013: First results from the survey of adult skills. Paris: OECD Publishing.

Republik Österreich. (2011). LLL:2020. Strategie zum lebensbegleitenden Lernen in Österreich. Retrieved from http://www.esf.at/esf/wp-content/uploads/LLL-Strategiepapier_20111.pdf 
Republik Österreich. (2015). Ministerialentwurf betreffend ein Bundesgesetz über den Nationalen Qualifikationsrahmen (NQR-Gesetz). Retrieved from http://www.parlament.gv.at/PAKT/VHG/XXV/ ME/ME_00152/index.shtml

Republik Österreich. (2016). Bundesgesetz über den Nationalen Qualifikationsrahmen (NQR-Gesetz). Retrieved from https://www.ris.bka.gv.at/GeltendeFassung.wxe?Abfrage=Bundesnormen\&Gesetzes nummer $=20009496$

Reutter, G. (2010). Inklusion durch Weiterbildung - für Langzeitarbeitslose eine utopische Hoffnung? In M. Kronauer (Ed.), Inklusion und Weiterbildung. Reflexionen zur gesellschaftlichen Teilhabe in der Gegenwart (pp. 59-101). Bielefeld: Bertelsmann.

Tritscher-Archan, S. et al. (2013). NQR K2-Simulationsphase. Provisorische QVS und wissenschaftliche Begleitung, im Auftrag des Bundesministeriums für Unterricht, Kunst und Kultur (unpublished).

\section{Monika Kastner}

Alpen-Adria-Universität Klagenfurt

Austria 